\title{
Past and Future Proliferators
}

The theory of nuclear opportunism performs well (though not perfectly) in explaining the way in which Britain, South Africa, and the United States thought about and used their nuclear weapons to advance their political goals. But how does the theory perform in explaining the behavior of other states that have acquired nuclear weapons? Further, what does the theory predict for potential future cases of proliferation?

Limited primary sources for many of the cases of nuclear acquisition means that drawing strong conclusions is difficult: without access to evidence about the internal deliberations of senior policymakers, it can be hard to definitively assess the role that nuclear weapons play. Nonetheless, it is worth making an initial assessment of whether the theory of nuclear opportunism appears to offer a plausible explanation for the way in which other states have changed their foreign policies after acquiring nuclear weapons. In this chapter, I examine whether Pakistan, India, France, Israel, and China appear to have responded to nuclear acquisition in the way the theory of nuclear opportunism suggests, and use the theory to make predictions for how Iran, Japan, and South Korea would behave if they acquired nuclear weapons. I do not try to use the case of the Soviet Union to test the theory: as discussed in chapter 4 with respect to the United States, the lack of a clear pre-nuclear baseline for behavior and the considerable flux of the international system in the early days of the Cold War make testing the predictions of the theory more difficult, especially given the much more limited availability of primary documents than for the United States. ${ }^{1}$ Similarly, because of substantial uncertainty about North Korea's nuclear posture (and thus, when North Korea acquired the theoretically relevant capabilities), I do not attempt to test the theory using the North Korean case. Depending on how North Korea has conceived of the utility of its nuclear weapons, acquisition could have occurred as early as 1993, or as late as 2017, when North Korea successfully tested a high-yield nuclear weapon and missiles with the ability to target the United States. ${ }^{2}$

As would be expected, the theory of nuclear opportunism performs better in some cases than others. The theory performs well in explaining Pakistani, 
Indian, and French behavior in the aftermath of acquiring nuclear weapons. However, the theory performs less well in explaining Israeli behavior and gets the Chinese case largely wrong. Nonetheless, overall, the theory receives significant validation and outperforms the alternative explanations.

\section{Pakistan}

Ever since the partition of British India in 1947, Pakistan has faced a serious territorial threat from India. India possesses considerably greater conventional military power than Pakistan, and a far larger economy, population, and territory. Moreover, India's military superiority over Pakistan has been repeatedly demonstrated, with India besting Pakistan in each of the wars they have fought (in 1947, 1965, 1971, and 1999). Most dramatically, in the 1971 war, India dismembered Pakistan, creating the new state of Bangladesh out of East Pakistan, and what remains of Pakistan's territory (previously West Pakistan) is geographically vulnerable to an Indian conventional assault. It is not surprising that in the aftermath of the 1971 humiliation, Pakistani leaders vowed to acquire nuclear weapons: to "eat grass" if necessary in order to acquire the capabilities that might deter India from taking similar actions in the future. ${ }^{3}$ Although Pakistan did not test nuclear weapons publicly until 1998, it acquired a nuclear capability by the mid-to-late 1980s. ${ }^{4}$

The theory of nuclear opportunism predicts that Pakistan, facing a severe territorial threat, would use nuclear weapons to facilitate aggression and steadfastness. The theory predicts that pursuing independence from its allies such as China or expanding its interests in South Asia or beyond would be impractical and unattractive goals for Pakistan even with nuclear weapons because of Pakistan's overwhelming need to focus on the Indian threat and its need for assistance from any and all sources. According to the theory, Pakistan would choose to use its nuclear weapons to improve its position vis-à-vis India, and would therefore use nuclear weapons to facilitate aggression and steadfastness.

These predictions are realized: Pakistan began using nuclear weapons to advance its political interests by standing more firmly when provoked and in pushing harder to revise the status quo. In the Brasstacks Crisis of 19861987, triggered by a large-scale Indian military exercise that Pakistani leaders feared might be a prelude to an invasion, Pakistan engaged in at least some degree of nuclear signaling to deter Indian aggression. Most notably, A. Q. Khan, the "father" of the Pakistani bomb program, gave an interview in which he stated that "nobody can undo Pakistan or take us for granted.... Let it be clear that we shall use the bomb if our existence is threatened." ${ }^{\prime \prime}$ However, the interview was not published for several weeks, and it remains unclear whether his threats were officially sanctioned by the government or whether they affected Indian behavior. ${ }^{6}$ 
Future crises between India and Pakistan would see more overt Pakistani nuclear signaling. In 1990, believing that India might respond to Pakistani support for insurgents in Indian-controlled Jammu and Kashmir, Pakistani leaders met and determined the need to "deter this impending threat." ${ }^{\prime 7}$ The way in which Pakistan chose to do so had a clear nuclear dimension. Pakistani Army Chief General Aslam Beg stated that "a squadron of [nuclear-capable] F-16s was moved . . . and we pulled out our devices and all to arm the aircraft... Movement was made in a way that is visible, because the purpose was not to precipitate a crisis but to deter." ${ }^{\prime 8}$ Other acts of nuclear signaling also took place: Pakistan sent Foreign Minister Shahabzada Yaqub-Khan to Delhi to convey that Pakistan would hold India responsible for any attack, a message understood to have a nuclear dimension and with Beg confirming that "Yaqub-Khan did a good job frightening them."

In 1999, in the aftermath of India's and Pakistan's nuclear tests, the Pakistani military took action across the Line of Control to seize territory in Indian-controlled Kashmir. Pakistan's actions triggered Indian retaliation and led to the Kargil War, with Pakistan ultimately forced back to the prewar status quo. ${ }^{10}$ However, India's retaliation was extremely measured, with Indian leaders careful to avoid crossing the Line of Control. This restraint stands in stark contrast to Indian actions in response to prior acts of Pakistani aggression: in response to a similar Pakistani operation in 1965, India had retaliated across the Line of Control and the international border into core Pakistani territory. ${ }^{11}$ In 1999, Pakistani nuclear weapons deterred an Indian response of this sort. Pakistan brandished its nuclear weapons during the crisis, with Pakistani foreign secretary Shamshad Ahmad publicly threatening to "use any weapon in our arsenal to defend our territorial integrity." 12 This rhetoric was backed up by action: the evidence suggests that the Pakistani military moved and readied nuclear assets for potential use (possibly without the knowledge of the civilian leadership). ${ }^{13}$ The evidenceincluding statements from Indian officials with every incentive to deny the deterrent effects of Pakistan's nuclear weapons-suggests that it was Pakistani nuclear weapons that restrained India's response. When Indian prime minister Atal Bihari Vajpayee was told that opening a second front against Pakistan across the border might be militarily necessary, Vajpayee reportedly looked shocked and responded, "But General Sahib, they have a nuclear bomb!"14 The Indian national security advisor Brajesh Mishra confirmed this fear, stating that the use of "nuclear weapons would have been risked if we did [cross the Line of Control]." ${ }^{15}$ And in a report by the Kargil Review Committee, analysts commissioned by the Indian government concluded that "Pakistan was convinced that its nuclear weapons capability would deter India's superior conventional forces."16

Since the Kargil War, Pakistani leaders have continued to engage in aggression against India, notably by using Pakistani-sponsored insurgents and terrorists against Indian cities. The December 2001 attack on the Indian 
Parliament by Jaish-e-Mohammed and Lashkar-e-Taiba (two Pakistanisupported militant organizations), the November 2008 attacks by Lashkare-Taiba militants against Mumbai, and the February 2019 Jaish-e-Mohammed suicide attack against Indian security forces in Kashmir are the most prominent examples, but Pakistani support for militants operating on Indian territory has been an increasingly prominent feature of Pakistani foreign policy. In each case, Indian leaders have been deterred from taking large-scale conventional military action in response. ${ }^{17}$ Scholars have typically concluded that Pakistani nuclear weapons enable this aggression against India, much as the theory of nuclear opportunism expects. C. Christine Fair argues that nuclear weapons "increase the cost of Indian action" against Pakistan, which facilitates "risk-seeking behavior ... to change the status quo."18 For Vipin Narang, Pakistan's nuclear weapons-and the aggressive nuclear posture it has adopted-have "enabled Pakistan to more aggressively pursue longstanding, limited revisionist objectives against India."19 For Paul Kapur, "nuclear weapons ... encouraged aggressive Pakistani behavior." 20 There is now a broad scholarly consensus that Pakistan uses nuclear weapons in this way. ${ }^{21}$ Regular statements by Pakistani elites reinforce the conclusion that Pakistan's nuclear weapons have inhibited Indian responses to Pakistani aggression. Jalil Jilani, a high-ranking official within the Ministry of Foreign Affairs, stated that "since Pakistan's acquisition [of a nuclear capacity], Pakistan has felt much less threatened" by Indian conventional capabilities. ${ }^{22}$ Prime Minister Benazir Bhutto stated that Pakistani decision makers had concluded that Pakistan's "nuclear capability would ensure that India could not launch a conventional war, knowing that it if did, it would turn nuclear."23 Feroz Khan, a brigadier general (retired) in the Pakistani Army and a former director in the Strategic Plans Division that formulated Pakistan's nuclear policy and strategy, has written that Pakistan's "nuclear capability ensures defense against physical external aggression and coercion from adversaries, and deters infringement of national sovereignty." 24

Overall, Pakistan appears to conceive of the utility of its nuclear weapons in exactly the way the theory of nuclear opportunism expects: as a tool for advancing its interests against the serious territorial threat posed by India. Pakistani behavior since acquiring nuclear weapons also seems consistent with the theory of nuclear opportunism: it is widely accepted that Pakistan uses nuclear weapons to facilitate both aggression and steadfastness, enabling Pakistan to both push harder in pursuit of long-held revisionist goals and to stand firmer when challenged.

\section{India}

India's decades-long path to nuclear acquisition stands in marked contrast to Pakistan's dash to acquire nuclear weapons. India first began pursuing 
nuclear technologies in the late 1940s and accelerated its interest in nuclear explosives in the 1960s in the aftermath of its defeat in the 1962 Sino-Indian war and China's 1964 nuclear test. Domestic political dynamics, however, prevented a firm decision to acquire nuclear weapons, and the 1974 test of a "Peaceful Nuclear Explosive" did not lead to an all-out effort to weaponize India's nuclear capability. India ultimately remained a threshold nuclear state until the late 1980s. At this point, Pakistan's acquisition of nuclear weapons provided the final impetus for Prime Minister Rajiv Gandhi, a supporter of multilateral nuclear disarmament, to push India's nuclear program over the finish line and acquire a fully fledged nuclear weapons capability. Although India would not publicly test its nuclear weapons until 1998, it had a functional nuclear weapons capability from the late 1980s. ${ }^{25}$

Because India faced a relatively benign security environment, and with domestic politics driving many key decisions in India's slow development of nuclear capabilities, it is far from obvious that nuclear weapons would have any significant effect on India's foreign policy. Despite this, the theory of nuclear opportunism does seem to shed some light on the ways in which Indian foreign policy changed after India acquired nuclear weapons.

What predictions does the theory of nuclear opportunism make? First, India did not face serious territorial threats when it weaponized its nuclear capabilities in the late 1980s. Not only does India possess a large territory and considerable strategic depth, but its plausible opponents would face serious challenges if they attempted to attack India: Pakistan is conventionally much weaker than India, while China would have to cross the formidable geographic barrier of the Himalayas. ${ }^{26}$

Second, India did not have a senior ally providing for its security when it acquired nuclear weapons: although India had signed the Indo-Soviet Treaty of Friendship and Cooperation with the Soviet Union in 1971, it did not commit the Soviet Union to India's defense. In any case, India's relationship with the Soviet Union had been deteriorating since the early 1980s, and Soviet leader Mikhail Gorbachev's "New Thinking" foreign policy indicated that the Soviet Union's global ambitions and commitments were being wound down by the time India acquired nuclear weapons. ${ }^{27}$ India was, however, rising in relative power by the late 1980s. For example, India's Correlates of War CINC score had been rising consistently since 1980. The theory of nuclear opportunism would therefore predict that Indian elites would see nuclear weapons as a tool for expanding Indian influence in the world and bolstering any existing junior allies.

In line with these predictions, the desire to expand India's position and status in the world is widely regarded to have been an important driver of Indian nuclear acquisition. T. V. Paul and Baldev Raj Nayar argue that "a key underlying reason for the acquisition of nuclear capabilities ... is the enduring and deep-rooted aspiration of India for the role of a major power, and the related belief that the possession of an independent nuclear capability is an 
essential prerequisite for achieving that status. ${ }^{28}$ George Perkovich makes a similar argument that Indian leaders were not driven toward nuclear acquisition by narrow security threats. Instead, Indian leaders as early as Prime Minister Jawarharlal Nehru and his chief nuclear scientist Homi Bhabha recognized that a "nuclear weapon capability could enhance India's status and power in the Western-dominated world" and offered a "shortcut" to major power status. ${ }^{29}$ Vipin Narang concurs, arguing that Bhabha "had a keen interest in India being viewed as a modern scientific state and, like many nuclear scientists of that era, saw the ability to develop nuclear weapons as the pinnacle of scientific achievement." ${ }^{30}$ Relatedly, Jacques Hymans argues that Indian leaders have consistently possessed a "nationalist" NIC and have thus held high conceptions of Indian status, with these beliefs shaping India's nuclear decision making in profound ways. ${ }^{31}$

While a desire to improve its status and standing in the world was certainly a driver of India's nuclear weapons program, did India actually change its foreign policy in a manner consistent with these desires after acquiring nuclear weapons? Overall, India's foreign policies did change in a manner consistent with the predictions of the theory, although it is unclear whether nuclear weapons played a key role in causing the changes.

Consistent with the predictions, Indian foreign policy became dramatically more ambitious and outward looking as India emerged in the postCold War world as a nuclear-armed state. This expansion occurred despite the considerable political and economic turmoil that characterized India at the end of the Cold War, the fact that India emerged from the Cold War facing a more assertive (and newly nuclear armed) Pakistan on its border, and fears that the end of the Cold War would be particularly damaging for India's geopolitical position given the collapse of the Soviet Union, its partner since the 1971 treaty. Ross Munro, for example, argued in 1993 that "India's reach for great power status is in shambles. The keystone of Indian power and pretence in the 1980s, the Indo-Soviet link, is history." ${ }^{\prime 2}$ Despite this potentially challenging strategic environment, India's foreign policy became substantially more ambitious.

The shift to a more expansive, ambitious foreign policy had a number of components. First, India initiated the Look East policy—a broad effort to "develop political contacts, increas[e] economic integration and forg[e] security co-operation with countries of Southeast Asia" — which "marked a shift in India's perspective of the world." ${ }^{33}$ Second, India built diplomatic and military relationships with new allies, including Israel (after diplomatic relations were established in 1992), Turkey, and Iran. ${ }^{34}$ Third, India aggressively pursued economic liberalization and foreign investment, reversing decades of socialist economic policy. ${ }^{35}$ This included devaluing the rupee, raising the ceiling on foreign ownership, removing import and export controls, and reducing business tax rates. ${ }^{36}$ Fourth, India increased its investment in defense. Defense expenditure grew slowly during the 1980s: from 15.9 percent 
of government spending in 1980-1981 to 16.9 percent in 1987-1988, but jumped to 19 percent by 1990-1991 despite a severe balance-of-payment crisis. ${ }^{37}$ Fifth, Indian participation in international organizations became more vigorous: increasing engagement and participation in the Association of Southeast Asian Nations (ASEAN), making more prominent demands for a permanent seat on the UN Security Council, and playing a considerably larger role in international peacekeeping efforts. India had not participated in any UN peacekeeping missions since sending two infantry brigades to the Congo in the 1960s, but during the 1990s, India sent forces to Cambodia (1992-1993), Mozambique (1992-1994), Somalia (1993-1994), Rwanda (19941996), Angola (1989-1999), and Sierra Leone (1999-2001). Overall, it seems fair to say that India "regained some of its self-confidence in the 1990s," seeking to expand its international position and status. ${ }^{38}$

These changes were not, however, obviously driven by nuclear acquisition. Indeed, the massive shift in the international system that occurred close to the same time that India acquired nuclear weapons makes it hard to firmly attribute any change in behavior to Indian nuclear weapons. However, India has frequently used its "responsible" stewardship of nuclear weapons as a core component of its efforts to be taken seriously as a legitimate great power that contributes to global public goods. ${ }^{39}$ These claims were ultimately rewarded and legitimized by the 2005 US-India nuclear deal that future secretary of defense Ashton Carter described as having "openly acknowledged India as a legitimate nuclear power, ending New Delhi's 30-year quest for such recognition." 40 More broadly, it seems plausible that nuclear weapons-through the psychology- and identity-based mechanisms discussed in chapter 1-may have changed the way in which Indian leaders conceived of India's role in international politics, and thus facilitated the more expansive and ambitious Indian foreign policies of the 1990s. After all, and as discussed above, the desire for greater status and a more prominent position in international politics was a core driver of Indian pursuit of nuclear weapons and technologies.

\section{France}

France acquired nuclear weapons in a period of considerable uncertainty about its future status in the world. A previously great power with a large empire, France suffered the humiliation of defeat and occupation by Nazi forces during World War II and required liberation by foreign forces at its conclusion. France entered the Cold War economically weak, politically and geographically sandwiched between the two superpowers, and fearful of a revived and potentially nuclear-armed Germany. In this environment, France made a determined effort to acquire nuclear weapons ${ }^{41}$ France established the French Atomic Energy Commission in the aftermath of the war, tested 
its first nuclear weapon in 1960, and in 1964 acquired the Mirage IV bombers, which offered the delivery capabilities that would allow France to use nuclear weapons militarily. ${ }^{42}$

What effects does the theory of nuclear opportunism predict that nuclear weapons would have on French foreign policy? First, France did not face immediate and severe territorial threats in 1964: while the Soviet Union was certainly a threat, France was sufficiently geographically removed from the Soviet threat and was protected from the Soviet Union by large numbers of NATO forces (and nuclear weapons) in Germany. ${ }^{43}$ Second, France had a senior ally-the United States-committed to its security. Third, France was in long-run political decline. Much as Britain was in the same period, France was in the process of adjusting to its status as a medium-ranked power. This is confirmed by the Correlates of War Project: France's Correlates of War CINC score had been declining since the mid-1950s and would continue to do so after France acquired nuclear weapons. The theory would therefore predict that France would see nuclear weapons as serving a foreign policy role similar to that of Britain's nuclear weapons: as a tool to avoid dependence on the United States and to maintain its position in international politics. In terms of French behavior, the theory anticipates that France would use its nuclear weapons to facilitate independence from the United States and maintain its status in the world: standing more firmly in defense of the status quo and bolstering its junior allies. However, given that France had given up its major colonial possessions prior to 1964 and was not a state on NATO's front line, core French interests were not being regularly challenged in a way that would allow us to assess whether France used nuclear weapons to facilitate steadfastness. Similarly, because France lacked junior allies (France itself, of course, was a junior ally in NATO), we should not expect to see France use nuclear weapons to facilitate bolstering. The theory of nuclear opportunism, therefore, anticipates that France would primarily use nuclear weapons to facilitate independence from the United States.

This is what we see in the historical record. Scholars have consistently identified a desire for both independence and status as key drivers of the French nuclear program. David Yost begins his analysis of France's nuclear program with the statement that "rank and independence have been enduring occupations of French statecraft." ${ }^{44}$ Wolf Mendl agrees that French elites believed that nuclear weapons would allow France "to reassert its independence and position in the world." 45 Pierre Gallois argues that for France, nuclear weapons were "the instrument ... for attaining true national military independence." 46 And as Wilfred Kohl writes, "The nuclear force was intrinsically related to [French prime minister Charles de Gaulle's] political goals of ensuring France's independence and augmenting France's freedom of action in world affairs." 47

This scholarly consensus is unsurprising given the many public and private statements by Charles de Gaulle, the French prime minister from 1958 
to 1959 and president from 1959 to 1969 , that articulated the need for nuclear weapons to ensure French independence. De Gaulle stated that "American nuclear power does not necessarily and immediately meet all the eventualities concerning France," meaning that France needed to "equip herself with an atomic force of her own." 48 In 1958, in conversation with John Foster Dulles, de Gaulle argued that "only in this way [through the possession of French nuclear weapons] can our defence and foreign policy be independent, which is something we prize above everything else." 49 In public speeches he argued that a state "which does not possess [nuclear weapons] ... does not command its own destiny" and that "the countries which do not have an atomic arsenal ... have to accept a strategic and consequently a political dependency." 50 It was not only the United States from which France sought independence, but Britain as well: de Gaulle could not accept a situation in which "only the Americans and the British could in fact loose atomic war whenever they wanted." ${ }^{51}$ In terms of status, de Gaulle explicitly argued that the equalizing effect of nuclear weapons would allow France to maintain its status even in a world dominated by the superpowers: "While the megatons that we could launch would not equal in number those which Americans and Russians are in a position to unleash, once a certain level of nuclear strength is reached, the proportion of the respective military resources is no longer absolute. ... That is why France's modern armaments not only provide it with incomparable security but inject into a dangerous world a new and powerful factor for prudence and circumspection." ${ }^{152}$ Even receiving US assistance that might have imposed conditions on the development of the program was judged unacceptable: in de Gaulle's words, such assistance would be "incompatible with [French] sovereignty." ${ }^{33}$ However, the belief that nuclear weapons would serve these functions was not limited to de Gaulle and was more widely held among French political elites. After all, France had taken substantial steps toward acquiring nuclear weapons well before de Gaulle came to power. ${ }^{54}$ In the words of Defense Minister Jacques Chaban-Delmas, for example, "We intend to be able to make modern weapons in order to maintain an equitable balance within NATO." ${ }^{55} \mathrm{Or}$ as the military chief of staff told Premier Pierre Mendès-France in 1954, nuclear weapons would give France "the possibility of recovering a role [in international politics] of first rank." 56

Did France use nuclear weapons to facilitate a more independent foreign policy? France had long been uncomfortable with its subordinate position to the United States and Germany within NATO and took steps to preserve some element of independence. France pressured the United States for greater influence in NATO decision making and announced that its Mediterranean fleet would not be subject to NATO command in the event of war. France also demanded that US intermediate range ballistic missile (IRBM) deployments could not occur on French territory and that tactical nuclear weapons could not be kept in France. ${ }^{57}$ However, as its nuclear program 
achieved a full deliverable capability, French independence increased: the French "became less inclined to accept what it saw as the infringements on sovereign choice implied by its role in a U.S.-dominated alliance." ${ }^{\prime 5}$ And, in line with these concerns, shortly after acquiring a deliverable nuclear capability, France withdrew from NATO's command structure. France's willingness to take this dramatic step-in spite of the American anger that resultedwas directly motivated by a desire for greater independence within NATO. Furthermore, French leaders saw their ability to take this step as intimately tied to France's newly developed nuclear capabilities: in Yost's words, "Membership in NATO's integrated institutions was portrayed as a subjugation to foreign decisions. ... Strategic nuclear forces would give France the means of self-reliance and the option of non-belligerency in conflicts." 59

Withdrawal from NATO's command structure was not the only action that France took after acquiring nuclear weapons. For example, France criticized the Bretton Woods monetary system, actively pursued détente with the Soviet Union, and recognized the status of the PRC: all actions opposed by the United States.$^{60}$ By the 1970s, French officials were even prepared to make provocative statements about their ability to harm the United States with nuclear weapons. General Guy Méry, the chief of staff of the armed forces, stated that the "damage that we could cause to either superpower would immediately place it in such a situation of imbalance regarding the other superpower that it is doubtful that either could afford to tolerate suffering that damage at any time." ${ }^{\prime 61}$

Overall, the way in which nuclear weapons affected French foreign policy appears consistent with the theory of nuclear opportunism: French elites saw nuclear weapons as a tool to facilitate independence and, consistent with these views, behaved more independently after acquiring nuclear weapons.

\section{Israel}

Israel's desire for nuclear weapons emerged from its strategic environment. Since its founding in 1948, Israel has been a geographically vulnerable state with a small territory and population, surrounded by more populous neighbors with which it has fought numerous wars and which have regularly challenged the legitimacy of Israel's existence. For a country formed in response to the Holocaust and the historical persecution of the Jewish people, such vulnerability has added political salience. It is therefore unsurprising that Israel has sought to overcome its vulnerabilities through technological advancement and would seek the protection of nuclear weapons. ${ }^{62}$

As Israel's first prime minister David Ben-Gurion stated, "Science can provide us with the weapons that are needed to deter our enemies from waging war against us. I am confident that science is able to provide us with the weapon that will secure the peace, and deter our enemies." ${ }^{63}$ When Ben- 
Gurion made this statement, Israel was already close to acquiring a nuclear weapon. Israel had been pursuing nuclear technologies since the 1950s and ultimately assembled its first nuclear weapons (deliverable by existing Israeli Vautour aircraft) on the eve of the 1967 war. $^{64}$

Although it is widely understood that Israel possesses nuclear weapons, Israel has never officially acknowledged the existence of its nuclear program or status as a nuclear-armed power. This policy of "opacity" has had multiple drivers: to avoid forcing the United States to pick between its commitment to nonproliferation and its alliance with Israel, to reduce the domestic pressures pushing neighboring Arab states to respond by pursuing their own nuclear weapons, to reduce international pressure and sanctions, and to retain a source of diplomatic leverage over the United States by being able to threaten the public declaration of its nuclear capabilities.

What does the theory of nuclear opportunism predict in the case of Israel? The theory is clear because Israel faces severe territorial threats. Although Israel has triumphed in the wars it has fought against its Arab neighbors, it nonetheless faced serious threats when it acquired nuclear weapons on the eve of the 1967 war. Although the outcome of the 1967 war-a decisive victory in which Israel seized the Golan Heights, West Bank, Gaza Strip, and Sinai Peninsula-may suggest that the threats Israel faced were limited, the war could have unfolded very differently. Most notably, Israel's preemptive attack against the Egyptian army and air force had a profound effect on the way the conflict unfolded. ${ }^{65}$ Similarly, the manner in which the 1973 war unfolded, in which core Israeli territory was conquered before Israel was able to repel the invaders after being resupplied by the United States, demonstrates the vulnerabilities that Israel faced. The theory therefore predicts that Israel would use nuclear weapons to facilitate both aggression and steadfastness toward the threats it faced.

Whether we see this in the historical record is not entirely clear. While the secrecy surrounding Israel's nuclear program would make a definitive assessment of how nuclear weapons affected Israeli foreign policy extremely challenging, it is not clear that nuclear acquisition marked a clear discontinuity in Israeli foreign policy. It is possible that Israel's nuclear weapons emboldened the state to take aggressive and preemptive military actions that began the 1967 war, but it is equally plausible that it would have taken such actions regardless of its nuclear status. Ultimately, Israel's decisive victory with conventional forces meant that nuclear weapons did not play an obvious role in the conflict. As Avner Cohen argues, "Ideas [of seeking to gain political leverage from their nuclear weapons], to the extent that some individuals entertained them, apparently never reached discussions at the highest political forum." ${ }^{\prime 66}$ Indeed, in some ways, Israel's decision to pursue a preemptive conventional military strategy rather than take the gamble of conducting a nuclear test or unsheathing its nuclear capabilities may have indicated a lack of faith in the political power of nuclear weapons. 
There is stronger evidence that nuclear weapons provided Israel with political benefits in the 1973 Yom Kippur war, facilitating Israeli steadfastness in defense of the status quo. Israeli forces were caught off guard by a joint Egyptian and Syrian attack seeking to reclaim the Arab territories lost in the 1967 war, and Israeli forces suffered significant losses of territory and materiel in the opening days of the war. An Israeli defeat, previously considered unthinkable, appeared plausible, and Israeli officials feared that Syrian and Egyptian aims might not be limited to merely reclaiming the territory previously lost in the 1967 war. While Prime Minister Golda Meir rejected suggestions to explicitly threaten invading forces with nuclear weapons, Minister of Defense Moshe Dayan nonetheless ordered an increase in Israel's nuclear alert level, including operational checks on Israel's nuclear-capable Jericho missiles that would be observable by US intelligence. ${ }^{67}$ These checks played an important role in triggering US efforts to resupply Israel with conventional materiel and may have encouraged Syrian and Egyptian restraint, with the Syrian front line retreating rather than seeking to solidify its gains, especially in the northern sector where Syria could plausibly have achieved full control over the Golan Heights. ${ }^{68}$ Thus, both by restraining the behavior of Israel's opponents and by compelling greater assistance from the United States, nuclear weapons allowed Israel to stand more firmly in defense of the status quo.

Since the 1973 war, Israel's grand strategy has emphasized maintaining conventional military superiority, a policy supported by successive US administrations that have committed to maintaining Israel's "qualitative military edge." ${ }^{69}$ Conventional superiority has allowed Israel to stand more firmly in defense of the status quo, and, of course, is intimately related to Israel's nuclear weapons. Specifically, Israel's continued and implicit threat to unsheathe its nuclear capabilities provides additional motivation for Washington to ensure that Israel's conventional military superiority be maintained..$^{70}$ Israel, therefore, clearly receives political benefits from its nuclear weapons. Nonetheless, it is not clear that Israel has used its nuclear weapons to facilitate anything other than steadfastness.

While using nuclear weapons to facilitate steadfastness would be predicted by the theory of nuclear opportunism, the theory would also predict Israel using nuclear weapons to facilitate aggression, which we do not see clear evidence for in the historical record. Why might the theory perform less well in this case? It is plausible that factors left out of the theory play an important role in the case of Israel. For example, it is possible that the Israeli desire to maintain its relationship with the United States and to avoid provoking reactive proliferation by adversaries in the region leads Israel to avoid brandishing its nuclear weapons too overtly, or using its nuclear weapons to facilitate aggression. These two factors would not necessarily be expected to generalize to other cases, and it is reasonable to leave them out of a theory that seeks a balance between parsimony and explanatory richness. None- 
theless, the theory of nuclear opportunism receives only mixed and limited support from the case of Israel.

\section{China}

China first tested a nuclear weapon in October 1964 but did not follow the United States and Soviet Union in developing a large nuclear arsenal. ${ }^{71} \mathrm{Al}-$ though China's desire for nuclear weapons emerged in the aftermath of attempted nuclear coercion from the United States during the Korean War and in the 1954 crisis over Quemoy and Matsu, China has never sought to match the nuclear capabilities of either superpower. ${ }^{72}$ Instead, China's nuclear arsenal has remained limited in both qualitative and quantitative terms, or, in the words of Taylor Fravel and Even Medeiros, "small, unsophisticated, and, arguably, highly vulnerable."73 Chinese leaders have consistently believed that even a small arsenal can threaten sufficiently devastating nuclear retaliation to deter nuclear coercion and attack, and that a larger and more diverse arsenal was therefore unnecessary. ${ }^{74}$

What does the theory of nuclear opportunism predict in the case of China? First, China did not face severe territorial threats when it acquired nuclear weapons. China possessed an enormous territory granting it considerable strategic depth, and an impressive army: even against the might of the Soviet Red Army, China maintained a considerable conventional military advantage along the Sino-Soviet border throughout the 1960s and 1970s that was sufficient to deter and resist any invasion or aggression. ${ }^{75}$ Second, China did not have an ally committed to its protection: the Sino-Soviet alliance had fractured well before China acquired nuclear weapons. Third, China was rising in power. China's Correlates of War Project CINC score, for example, has been on an upward trajectory since the 1950s. The theory of nuclear opportunism would therefore anticipate that China would use nuclear weapons to facilitate the expansion of its influence in international politics, steadfastness in defense of the status quo, and bolstering of junior allies.

It does not appear, however, that Chinese strategic thinkers have ever thought that nuclear weapons offered China the ability to do much more than deter nuclear coercion by the superpowers (that is, anything beyond facilitating steadfastness). ${ }^{76}$ As Fravel and Medeiros write, "Mao Zedong and Deng Zioping, [who] had a consistently dominant influence on Chinese nuclear strategy ... viewed nuclear weapons, primarily and probably exclusively, as tools for deterring nuclear aggression and countering coercion." 77 In Mao's words, "If we don't want to be bullied, then we cannot do without this thing." ${ }^{178}$ Chinese leaders recognized that China required nuclear weapons to ensure its security and resist intimidation in an international environment dominated by two nuclear-armed superpowers, but believed that the number of nuclear weapons they needed was small. This view emerged 
directly from Mao's view of the importance of manpower rather than technology in determining the outcome of wars. Even as China has sought to modernize its arsenal, this has not reflected a fundamental shift in its understanding of the utility of nuclear weapons. Rather, Chinese modernization has aimed to maintain the ability to assure retaliation even as adversary capabilities have improved. ${ }^{79}$

These views are not consistent with the theory of nuclear opportunism and accord much more closely with the predictions of the theory of the nuclear revolution. Chinese leaders do not appear to have viewed nuclear weapons as a broadly useful political tool, but rather as a capability with very narrow political utility: resisting nuclear coercion and deterring nuclear attack. As with the case of Israel, it is plausible that factors left out of the theory of nuclear opportunism for reasons of parsimony play an important role in this case. Specifically, the distinctive ideational beliefs about the limited utility of nuclear weapons held by Mao and other Chinese leaders may have led both to China's relatively small and vulnerable nuclear force and to a reluctance to use nuclear weapons to achieve broader foreign policy goals. This factor does not appear to influence the effects of nuclear acquisition across a wide range of cases (and is therefore reasonably left out of a theory that aspires to retain parsimony and generalizability) but does appear to play a powerful role in the Chinese case.

\section{How Might Future Proliferators Behave?}

Although there are cases that the theory of nuclear opportunism does not explain well, the theory performs well overall. The theory offers a plausible explanation for the way in which the majority of states that have acquired nuclear weapons have both thought about the utility of their nuclear weapons and behaved after acquiring them.

It is thus reasonable to ask what the theory has to say about the ways in which future proliferators might behave. Specifically, I make predictions for how Iran, South Korea, and Japan would behave if they acquired nuclear weapons. Using the theory in this way demonstrates that it has the potential to offer policy-relevant insights into the potential behavior of future nuclear-armed states. While such predictions could prove to be wrong, the ability to make ex ante predictions that offer the possibility of falsification is a virtue of the theory. Thus, in addition to being relevant to ongoing policy debates, making such predictions also offers a test of the theory-for example, if Japan were to acquire nuclear weapons and engage in different behaviors than those predicted, that would provide an indication that the theory may be incorrect or require adjustment.

Of course, making these predictions requires some assumptions to be made. The theory makes predictions about the ways in which states that ac- 
quire nuclear weapons change their behavior after acquiring nuclear weapons. ${ }^{80}$ This means that one has to be cautious about using the theory to make predictions about countries that currently lack nuclear weapons: such predictions would apply only if that country were to acquire nuclear weapons. For example, in the context of Iran, the theory would apply only in a world in which Iran has acquired nuclear weapons. Envisaging such a world requires additional assumption-for example, that the United States has not taken military action to prevent Iranian nuclear acquisition.

If Iran were to acquire nuclear weapons, how does the theory of nuclear opportunism anticipate that Iranian foreign policy would change? The first variable is the existence of serious territorial threats or an ongoing war. Iran does not currently face such threats. The US invasion of Iraq in 2003 removed Iran's primary threat-Saddam Hussein's Iraq. Of course, the large numbers of US forces on Iran's borders with Iraq and Afghanistan posed a significant territorial threat to Iran, but the subsequent drawdown of US forces in both countries has reduced such dangers. Today, Iran faces weak and internally unstable neighbors that lack power projection capabilities and pose little territorial threat. ${ }^{81}$ In addition, despite a long history of intervention by outside powers that have substantially influenced the outlook of the Iranian regime and its military forces, Iran retains "extensive natural defenses" including mountain ranges that encircle much of the country and ensure that "Iran's periphery favors the defender and is ill-suited to maneuver warfare." 82 Similarly, while either the United States or Israel could conduct damaging air strikes against Iran, the possibility of either state invading and holding substantial portions of Iranian territory seems remote. ${ }^{83}$ Because Iran does not face such threats, the theory does not predict that Iran would find it attractive to use nuclear weapons as a shield behind which to facilitate aggression. ${ }^{84}$

The second variable is whether Iran possesses a senior ally that partially provides for its security. Iran lacks such an ally. While Russia and China have offered Iran some diplomatic protection in the face of US sanctions and threats, that diplomatic protection has not been absolute and neither country has the power projection capability to defend Iran militarily in a sustained way. It is unlikely that Iran views either country as a patron committed to its security. ${ }^{85}$ Nonetheless, to the extent that Iran does view Russia or China as providing for its military security, the theory anticipates that Iran would use nuclear weapons to facilitate independence from those patrons. The final variable is whether Iran is currently rising in power relative to its primary rivals in the region. Although power trends in the Middle East are notoriously fickle, it seems hard to argue that Iran is significantly rising in power at the present point in time. While the US withdrawals from Iraq and Afghanistan have removed a source of threat on Iran's borders and increased Iran's relative position in the region, Iran has also suffered unwelcome changes in the balance of power over the past few years (notably, the civil 
war threatening ally Bashar al-Assad in Syria, the ongoing effect of multilateral sanctions on the Iranian economy, and the rise of the Islamic State). Iran's economy remains hamstrung by sanctions, high inflation, and unemployment and is likely to remain poorly performing even in the event that some portion of the multilateral sanctions currently in place are lifted. ${ }^{86}$ Iran's military forces are outdated and poorly maintained. Further, Iran's defense budget is small compared with those of its rivals, with Iranian defense expenditure amounting to only a quarter of Saudi Arabia's. ${ }^{87}$

The theory of nuclear opportunism therefore anticipates that if Iran were to acquire nuclear weapons, it would use them to facilitate the bolstering of its allies and steadfastness in the face of threats. The theory does not predict the precise form such bolstering would take, but it would be reasonable to assume that it might involve increased resource transfers to existing allies such as Syria and Iraq, greater Iranian efforts to penetrate their domestic politics, and, perhaps, an implicit Iranian offer of extended deterrence to those states. In addition, Iranian bolstering need not only seek to boost other states. Given Iran's history of using proxies throughout the Middle East, such behavior might also be observed to a greater extent in its relationships with proxies than in its relationships with other states. Iran could seek to provide additional resources to Hizbullah, increase its influence over Hamas, or provide additional support to the Houthis in Yemen, as well as seeking greater influence over the governments in Baghdad, Damascus, and Sana'a. This prediction aligns with the expectations of Erica Borghard and Mira RappHooper, who predict that a "nuclear armed Iran may increase its support of proxies." $" 88$

The theory of nuclear opportunism thus offers mixed news to those concerned about how Iran would behave if it acquired nuclear weapons. While the theory suggests that Iran using nuclear weapons to facilitate territorial aggression against its neighbors such as Saudi Arabia or Iraq in the way that Pakistan has is unlikely, the prospect of greater Iranian bolstering of existing allies is not an outcome that most US policymakers would find reassuring. Greater Iranian steadfastness, while not actively threatening US interests, would nonetheless reduce US freedom of action in the region. The theory of nuclear opportunism thus offers something of a middle ground between pessimists and optimists when it comes to Iranian nuclear acquisition. ${ }^{89}$

What would the theory predict in the case of US allies such as Japan and South Korea? North Korea's nuclear advances—specifically, its demonstration in the summer of 2017 of both an intercontinental ballistic missile (ICBM) capable of hitting the continental United States and a high-yield nuclear weapon (either a two-stage thermonuclear device or a boosted fission weapon) - have raised doubts about the continued reliability of American extended deterrence. Japanese and South Korean statesmen might reasonably question whether they should rely on American protection in the face of potential North Korean aggression when North Korea can threaten to hold 
US cities at risk of devastating retaliation. Just as European allies doubted America's willingness to sacrifice Boston or New York for Bonn or Paris during the Cold War, US allies in Asia may well become increasingly skeptical of US commitments to sacrifice Seattle or Los Angeles to protect Tokyo or Seoul. If so, just as US allies such as Germany, Taiwan, and Sweden considered pursuing nuclear weapons during the Cold War, US allies may again begin to find nuclear weapons an attractive option.

For Japan, the predictions are similar to those made for the United Kingdom in chapter 2. Japan is protected by highly defensible sea borders, with a substantial buffer between its territory and that of its adversary. While both North Korea and China are seen as adversaries by Japanese leaders, they do not rise to the level of severe territorial threats. Japan does possess an ally dedicated to its protection (the United States) and is in long-run geopolitical decline thanks to an aging population and vigorously rising powers in the region. The theory of nuclear opportunism therefore predicts that if Japan acquired nuclear weapons, it would use them to facilitate independence from the United States and steadfastness in responding to threats (the theory would also predict Japan using nuclear weapons to facilitate bolstering of junior allies, but Japan does not currently have any alliances in which it is the senior partner).

For South Korea, the more severe threat posed by North Korea's military capabilities results in the theory of nuclear opportunism making different predictions. Much as with the case of Pakistan or Israel, the theory of nuclear opportunism predicts that South Korea would not seek to use its nuclear weapons to facilitate independence from the United States. Rather, South Korea would be more inclined to see nuclear weapons as a tool for improving its position on the Korean peninsula, and to use nuclear weapons to facilitate both aggression and steadfastness against North Korea. South Korea would likely respond more vigorously to North Korean provocations and might be more tempted to engage in aggression against North Korea itself, judging that its nuclear arsenal would restrain North Korean retaliation.

The theory thus anticipates different challenges for US foreign policy if Japan or South Korea were to acquire independent nuclear weapons. In the South Korean case, restraining South Korean aggression or retaliation after North Korean provocations may become a key task of US foreign policy, and South Korean nuclear weapons would be expected to lead to a more volatile and violent Korean peninsula. Japan, on the other hand, may be less likely to use nuclear weapons to facilitate aggression, but may become a less consistent ally of the United States and more inclined to chart its own course in international politics. In both cases, therefore, the theory of nuclear opportunism provides clear reasons why US policymakers would be concerned about the possibility of proliferation to either Japan or South Korea. 